\section{Evaluation of strategies by the Brazilian Ministry of Health to stimulate the municipal response to AIDS}

\author{
Avaliação de estratégias do Ministério da Saúde \\ para incentivar a resposta municipal a \\ AIDS no Brasil
}

Alexandre Grangeiro 1

Maria Mercedes Loureiro Escuder 2

Euclides Ayres de Castilho 1

\section{Introduction}

The aim of this study was to evaluate strategies by the Brazilian Ministry of Health to expand the municipal response to AIDS. Cities "included" and "not included" in Federal strategies for "municipalization" of the response were compared according to the response profile and trends in the epidemic. Multinomial logistic regression was used, among other statistical procedures. Municipalities included from 1994 to 1998 showed higher chances of providing HIV diagnostic testing [OR = 15.0; 95\%CI: 5.6-40.1], of having AIDS services [OR = 18.4; 95\%CI: 8.4-40.5], and reducing cases involving heterosexual [OR = 3.1; 95\%CI: 1.4-7.3], homosexual/bisexual [OR = 3.0; 95\%CI: 1.4-6.2], and IDU transmission [OR = 6.6; 95\%CI: 2.9-14.9] as compared to those "included in 2003" and "not included". There were no associations between the included Municipalities, greater coverage in prevention, the reduction in cases due to vertical transmission or blood transfusion, or mortality rates. Municipalities with a more structured response were associated with better results. The findings suggest that the municipalization policy contributed to improvement in the local response to AIDS.

Acquired Immunodeficiency Syndrome; Program Evaluation;DiseasePrevention;Descentralization
Brazil is known for the results achieved in its response to the AIDS epidemic 1,2,3, as evidenced by the stabilization in the HIV infection rates and number of AIDS cases 4 , the increase in safe sex practices 5,6 , reduction in situations involving prejudice 7 , and improvement in quality of life for persons with HIV 8 .

Various factors have been identified as responsible for achieving these results $1,2,9$, including the early Brazilian response, beginning in the early 1980s with the adoption of comprehensive guidelines that included universality, comprehensive care, defense of the rights of the most extensively affected groups, and participation by broad segments of society.

Another important contribution came from the organizational structure of the Unified National Health System (SUS) 1,2,9. Based on decentralization (including down to the municipal level), unified managerial control at each level in the system, and social control, the structure enabled States and Municipalities to implement policies for prevention and care of sexually transmitted infections (STI) and AIDS 4,10.

Policies implemented at the local level largely reflected initiatives by the Ministry of Health, that, since 1994, induced the strengthening of AIDS programs in areas where the epidemic was expanding significantly. This article will refer to the Ministry of Health's induction of the local re- 
sponse as "strategies for municipalization or expansion of the response to AIDS", a process that was implemented in two phases. The first, lasting from 1994 to 2002, was partially financed through loan agreements with the World Bank 11, subsidizing activities by 27 State Health Departments and 151 priority Municipalities, which at the time accounted for more than $70 \%$ of the AIDS cases in Brazil.

The second phase, launched in 2003, was charaterized by the institutionalization of financing for AIDS-related activities according to the rules of the SUS. To this end, it was used as a reference so-called "Incentive Policy", which allow the transfer of additional Federal funds to the States and Municipalities. This transfer is conditioned on the implementation of specific actions and compliance with prerequisites, in the case of AIDS, for example, co-financing of activities and annual submission of Action and Target Plans approved by the Health Councils and InterManagerial Commissions 12,13,14.

Since the establishment of the Incentive Policy for AIDS programs, various evaluations have been performed 12,13,14, showing, among other results, an increase in the number of Municipalities included in the strategies for expansion of the response, which were selected on the basis of recommendations by the Bipartite Inter-Managerial Commissions (consisting of State and Municipal Secretaries of Health) and epidemiological relevance, defined by the number of AIDS cases, incidence rate, and population and size. There was also an increase in funds transferred by the Ministry of Health and an improvement in the management process.

Due to the short time transpired since implementation, the evaluations have not allowed more in-depth knowledge of the profile of activities and their relationship to the epidemic. This motivated the Department of STD, AIDS, and Viral Hepatitis under the Ministry of Health (PNDST/AIDS) to request a new study. Some of the findings are presented in this article and address two questions: "What are the characteristics of the response and of the Municipalities included in the Incentive Policy?" and "What possible influence could this Policy have on trends in the epidemic and AIDS-related mortality rates?".

\section{Methodology}

A evaluation study was conducted with Municipalities that had qualified for the Incentive Policy as of December 30, 2008. These Municipalities were characterized first according to geopolitical and epidemiological indicators and health services supply. Next, the profile of the programmatic response was analyzed within the context of the Incentive, in relation to scope, inclusion of population groups, sustainability, and intervention capacity. Finally, the Municipalities included in the Policy were compared to others not included in order to observe differences in the degree of implementation of the response and trends in the epidemic.

Secondary data were used in order to characterize the Municipalities and analyze differences between those included and not included. Epidemiological, geopolitical, and health structure indicators were used, including procedures performed in the SUS, with data obtained from the System's Information Technology Department (DATASUS. http://w3.datasus.gov.br/datasus/ datasus.php, accessed on 14/Nov/2008). The Brazilian National STD/AIDS Program provided the data on AIDS diagnostic and treatment services, the clinical and immunological situation of persons with HIV, and the supply of CD4+/ CD8+ T-cell tests. The Municipal Human Development Index (HDI-M) was extracted from the website of the United Nations Development Program (http://www.pnud.org.br/atlas/, accessed on 18/Jul/2008). Analysis of the response profile induced in the context of the Incentive Policy drew on information by the Action and Target Plans 15 submitted by the Municipalities in order to receive Federal funds in 2006. Fifty-four new Municipalities were only included more recently, in 2007 and 2008, and were thus not included in the current analysis.

The indicators used to characterize the $\mathrm{Mu}$ nicipalities in the first phase of the evaluation were: (a) geopolitical: geographic regions of the country; population estimate for 2006; and HDI-M in 2005; (b) epidemiological, considering the years 2002-2006: absolute number of cases reported and categorized according to magnitude (50 or more cases; 20-49; and 1-19); mean annual incidence rate per 100 thousand inhabitants; existence of reporting (yes/no) of cases in a given transmission category; number of transmission categories with cases reported during the period; and time since onset of the epidemic, calculated from the year in which the first case was reported in the Municipality; and (c) health structure in 2005: per capita health expenditures; and primary healthcare procedures as a proportion of total procedures performed under the SUS.

For a profile analysis of the Municipal AIDS programs' response, the Action and Target Plans were reviewed systematically and the relevant information was categorized dichotomously according to a predefined script. Such information included: (a) the scope of the response: measured 
by the existence (yes/no) of targets in the Action and Target Plan, contemplating care for persons with HIV; reduction of vertical transmission of HIV and syphilis; diagnosis of HIV infection; prevention in vulnerable populations and the general population; and/or diagnosis and treatment of STI; (b) populations covered: having included targets in the area of care for persons with HIV, STI, pregnant women, and HIV-exposed children, and in the area of prevention among adult and young jail inmates, men who have sex with men, male and female sex workers, drug users, injecting drug users (IDU), transvestites and transgenders and/or other vulnerable population groups like truck drivers and indigenous peoples; (c) priority area for intervention: area (prevention/care) that received the most funds in the Action and Target Plan and have spent more resources for the general population; (d) sustainability: having allocated resources from the health departments in the areas of care and prevention; and (e) capacity for intervention in the epidemic: having invested the largest proportion of the resources in the supply of services to the population in the areas of prevention and care.

This stage of the study used cluster analysis with the K-means technique. The criterion used to select the model was the potential for interpreting the established groups, which finally consisted of four clusters (response profiles). The clusters/profiles were compared according to the Municipalities' demographic and epidemiological indicators, by means of the chi-square statistic for categorical variables, and when they were considered significant ( $\mathrm{p}<0.05)$, standardized residuals analysis (Zres) was used 16. This technique allowed analyzing differences between the observed and expected values in contingency table cells, and for this study values greater than 1.96 were defined as concentration/excess of Municipalities, and values less than -1.96 were defined as absence/lack of Municipalities. In the case of continuous variables, ANOVA was used, with Bonferroni inequality to test multiple differences between means.

For comparison of the Municipalities included and not included in the Incentive, it was assumed that the Municipalities included in the strategies to expand the response to HIV had greater capacity to intervene in and control the epidemic. It was further assumed that the $\mathrm{Mu}$ nicipalities with a greater supply of services for diagnosis, prevention, and care and with a reduction in AIDS cases and mortality rates had higher chance of having been included longer in the municipalization strategies. Meanwhile, the more recently included Municipalities are only associated with a greater supply of services and decrease in mortality, and not with a reduction in cases, since there has not been sufficient time to observe such a trend. The inverse situation is observed with the mortality rate, which should decrease after an increase in the supply of services.

Thus, for the analysis, the Municipalities belonging to the Incentive Policy were subdivided according to time since inclusion in the strategies to expand the response: (1) older Municipalities, included from 1994 to 1998, and (2) more recent Municipalities, included since 2003 with the establishment of the Incentive Policy. The group of Municipalities not included in the Incentive was selected among Brazilian cities with reported AIDS cases from 2002 to 2006, with the inclusion criterion defined as having reported at least 20 cases spread over the course of at least three years in the period analyzed. This criterion was used to allow comparison between the Municipalities with larger and more regular epidemics.

The indicators used in the comparison, categorized dichotomously (yes/no), were: (a) reduction of the epidemic by transmission category, calculated as the difference in the number of cases during the periods 1997-2001 and 2002-2006, considering the categories homosexuals/bisexuals, heterosexuals, IDU, transfusion recipients (of blood/blood products), and vertical or mother-to-child HIV transmission. "Reduction" was defined as those with a negative variation, and the others were categorized as "not reduced", including Municipalities which, in a given transmission category, did not show a variation in the number of cases or showed zero cases during the periods analyzed; (b) reduction in the AIDS mortality rate, also calculated as the difference between the mean rates in 19982002 and 2003-2007 and categorized according to the same criteria used in case reduction; (c) having presented, from 2003 to 2006, a proportion of patients with late HIV diagnosis above the mean (62.5\%) for Brazilian Municipalities, with "late" defined as cases that began clinical follow-up with CD4+/CD8+ T-cell count less than $200 / \mathrm{mm}^{3}$ or with AIDS-related symptoms/ diseases, or were only diagnosed at death; (d) having presented, from 2003 to 2006, a proportion of patients with HIV diagnosis at the time of death above the mean (33.3\%) for Brazilian Municipalities; (e) having presented, in 2006, the mean number of CD4+/CD8+ T-cell tests per patient above the mean (1.69/patient) for Brazilian municipalities; (f) existence of AIDS outpatient clinics in the Municipality in 2007; (g) existence of Voluntary Counseling and Testing Centers (VCT) in 2005, or an annual supply of HIV tests performed under the SUS higher than the mean (17.1 per thousand inhabitants) in the Brazilian 
municipalities from 2005 to 2007; (h) more than $75 \%$ of the schools in the Municipality conducting prevention activities in 2005; and (i) mean number of STI/AIDS consultations in primary care per 100 thousand inhabitants above the mean for Brazilian municipalities (5.5 per 100 thousand inhabitants) from 2003 to 2005.

The statistical procedure used for comparison of Municipalities was multinomial logistic regression 17, with the model having included all the analytical variables, which were eliminated successively, using as the criterion the descriptive significance level $(\mathrm{p}>0.10)$ and the least alteration in the odds ratios.

To minimize possible confounding effects, the analysis controlled for time since the beginning of the epidemic, complexity of the health system (proportion of primary procedures), and population size. In relation to the first variable, the idea was to control the effects related to possible depletion of the number of cases due to time since the epidemic began. In the second variable, the attempt was to keep the preexisting health structures from influencing the analysis of services supply, assuming a larger number of AIDS outpatient clinics in Municipalities with a predominance of high and medium-complexity procedures, while in those with a greater preponderance of primary care there would be an expansion in diagnostic and preventive activities. Controlling for population size aimed to minimize the effects of different contexts on trends in the epidemic and services supply and also provides an indirect measure to adjust for the size of the epidemic, which tends to be larger in large cities. For evaluation of the mortality rates, hierarchical models were considered, conducted without and with the variables "HIV infection diagnosis" and "AIDS outpatient clinics". The database management and statistical analysis were done with SPSS version 16.0 for Windows (SPSS Inc., Chicago, USA).

\section{Results}

The study sample consisted of 812 Municipalities, of which 332 (40.8\%) were not included and 480 (59.1\%) were included in the Incentive Policy. Among the latter, 151 (18.6\% of the total sample) were included in the municipalization strategies from 1994 to 98 and 329 (40.5\% of the total sample) since 2003. As shown in Table 1, the Municipalities that were included had older (20.4 years) and more complex epidemics, more cases $(92.9 \%$ of the total studied), mean incidence of 24.5 per 100 thousand/inhabitants, and diversification of HIV transmission forms $(84.8 \%$ with the concur- rent presence of heterosexual, homosexual/bisexual, and IDU transmission).

These Municipalities also had a HDI-M (0.78) higher than the national mean and were concentrated mainly in the Southeast region and in cities with more than 100 thousand inhabitants, totaling $88 \%$ of the study population and all the State capitals. The health structure was characterized by greater per capita expenditure ( $\mathrm{R} \$ 191.81 /$ inhabitant) and a slight predominance (51.4\%) of primary care among the total procedures performed under the SUS.

These characteristics were most prominent in Municipalities included from 1994 to 1998, which had the most AIDS cases, the highest mean incidence rate, and a health system that mainly performed medium and high-complexity procedures. In comparison to these Municipalities, the ones included in 2003 showed modest differences in the time since the onset of the epidemic (19.6 years) and geographic location. The most striking differences were the lower proportion both of cities with large ( $>50$ ) numbers of AIDS cases (66.6\%) and cases in the IDU and vertical transmission categories $(81.2 \%$ and $64.4 \%$, respectively).

An analysis of the programmatic response in the Municipalities included in the Incentive Policy (Tables 2 and 3) showed four profiles, characterized by different degrees in the scope of the response, sustainability, capacity to intervene in the epidemic, and inclusion/exclusion of priority population groups. These response profiles were as follows:

a) Profile 1, with a comprehensive and sustainable response and greater capacity for intervention: consisted of 91 Municipalities (21.3\%); presented the best indicators for sustainability (51.6\%) and investments in the supply of services and care for the population (100\%); the group with the second best performance in reaching the set of minimum goals $(82.4 \%)$, which included, concurrently, healthcare for persons with HIV, HIV diagnosis, prevention of vertical HIV transmission, and prevention in the overall population and specific groups. This was the group of Municipalities with the best separate performance in diagnosis and treatment of STI (84.6\%), HIV diagnosis (100\%), and prevention in specific population groups $(96.7 \%)$. These cities also showed the highest inclusion of drug users $(61.5 \%)$ and jail inmates $(26.4 \%)$, the second highest inclusion of transvestites $(17.6 \%)$, other vulnerable population groups $(79.1 \%)$, and, concurrently, care for persons with HIV, STI carriers, pregnant women, and HIV-exposed children (50.5\%). This group, mainly cities with 200 thousand inhabitants or more (Zres: 4.38) and 
Characteristics of the Municipalities included and not included in the Ministry of Health's Incentive Policy for AIDS. Brazil, 2009.

\begin{tabular}{|c|c|c|c|c|c|c|c|c|c|c|}
\hline \multirow[t]{3}{*}{ Characteristics } & \multicolumn{6}{|c|}{ Included } & \multirow{2}{*}{\multicolumn{2}{|c|}{ Not included }} & \multirow{2}{*}{\multicolumn{2}{|c|}{$\begin{array}{l}\text { Total number of } \\
\text { Municipalities }\end{array}$}} \\
\hline & \multicolumn{2}{|c|}{1998} & \multicolumn{2}{|c|}{2003} & \multicolumn{2}{|l|}{ Total } & & & & \\
\hline & $\mathbf{n}$ & $\%$ & $\mathbf{n}$ & $\%$ & $\mathbf{n}$ & $\%$ & $\mathbf{n}$ & $\%$ & $\mathbf{n}$ & $\%$ \\
\hline Municipalities & 151 & 31.5 & 329 & 68.5 & 480 & 59.1 & 332 & 40.8 & 812 & 100 \\
\hline \multicolumn{11}{|l|}{ Geographic region } \\
\hline Central & 11 & 7.3 & 20 & 6.1 & 31 & 6.5 & 27 & 8.1 & 58 & 7.1 \\
\hline North & 10 & 6.6 & 8 & 2.4 & 18 & 3.8 & 19 & 5.7 & 37 & 4.6 \\
\hline Northeast & 24 & 15.9 & 61 & 18.5 & 85 & 17.7 & 71 & 21.4 & 156 & 19.2 \\
\hline South & 41 & 27.2 & 60 & 18.2 & 101 & 21.0 & 82 & 24.7 & 183 & 22.5 \\
\hline Southeast & 65 & 43.0 & 180 & 54.7 & 245 & 51.0 & 133 & 40.1 & 378 & 46.6 \\
\hline Mean HDI-M & 0.8 & & 0.77 & & 0.78 & & 0.75 & - & 0.77 & \\
\hline Total population (2006) & $79,363,218$ & 62.8 & $31,809,593$ & 25.2 & $111,172,811$ & 88.0 & $15,160,491$ & 11.8 & $126,333,302$ & 100 \\
\hline$\geq 100,000$ & 134 & 88.7 & 116 & 35.3 & 250 & 52.1 & 14 & 5.3 & 264 & 32.5 \\
\hline$<100,000$ & 17 & 11.3 & 213 & 64.7 & 230 & 47.9 & 318 & 58.0 & 548 & 67.5 \\
\hline $\begin{array}{l}\text { Number of AIDS cases } \\
(2002-2006)\end{array}$ & 126,421 & 75.4 & 29,472 & 17.6 & \multicolumn{5}{|c|}{$(2002-2006)$} & 100 \\
\hline $1-19$ & - & - & 26 & 7.9 & 26 & 5.4 & - & - & 26 & 3.2 \\
\hline $20-49$ & 1 & 0.7 & 84 & 25.5 & 85 & 17.7 & 282 & 84.9 & 367 & 45.2 \\
\hline$\geq 50$ & 150 & 99.3 & 219 & 66.6 & 369 & 76.9 & 50 & 15.1 & 419 & 51.6 \\
\hline $\begin{array}{l}\text { Mean incidence per } \\
\text { 100,000 inhabitants } \\
(2006)\end{array}$ & 33.7 & - & 20.2 & - & 24.5 & - & 20.7 & - & 22.9 & - \\
\hline $\begin{array}{l}\text { Mean time since onset } \\
\text { of epidemic (years) }\end{array}$ & 22.0 & & 19.6 & & 20.4 & & 17.5 & - & 19.7 & \\
\hline \multicolumn{11}{|l|}{$\begin{array}{l}\text { Presented transmission } \\
\text { categories }\end{array}$} \\
\hline Heterosexual & 151 & 100 & 329 & 100 & 480 & 100 & 332 & 100 & 812 & 100 \\
\hline Homosexual/Bisexual & 150 & 99.3 & 316 & 96.0 & 466 & 97.1 & 286 & 86.1 & 752 & 92.6 \\
\hline IDU & 145 & 96.0 & 267 & 81.2 & 412 & 85.8 & 209 & 63 & 621 & 76.5 \\
\hline Vertical transmission & 141 & 93.4 & 212 & 64.4 & 353 & 73.5 & 150 & 45.2 & 503 & 61.9 \\
\hline $\begin{array}{l}\text { Transfusion (blood/ } \\
\text { blood products) }\end{array}$ & 48 & 31.8 & 36 & 10.9 & 84 & 17.5 & 14 & 4.2 & 98 & 12.1 \\
\hline $\begin{array}{l}\text { Heterosexual, } \\
\text { homosexual/bisexual } \\
\text { and IDU }\end{array}$ & 144 & 95.4 & 263 & 79.9 & 407 & 84.8 & 180 & 54.2 & 587 & 72.3 \\
\hline \multicolumn{11}{|l|}{$\begin{array}{l}\text { Number of transmission } \\
\text { categories }\end{array}$} \\
\hline One & - & - & 8 & 2.4 & 8 & 1.7 & 9 & 2.7 & 17 & 2.1 \\
\hline Two & 2 & 1.3 & 30 & 9.1 & 32 & 6.7 & 81 & 24.4 & 113 & 13.9 \\
\hline Three & 13 & 8.6 & 97 & 29.5 & 110 & 22.9 & 153 & 46.1 & 263 & 32.4 \\
\hline Four & 88 & 58.3 & 169 & 51.4 & 257 & 53.5 & 84 & 25.3 & 341 & 42.0 \\
\hline Five & 48 & 31.8 & 25 & 7.6 & 73 & 15.2 & 5 & 1.5 & 78 & 9.6 \\
\hline \multicolumn{11}{|l|}{$\begin{array}{l}\text { Showed decrease in } \\
\text { cases in transmission } \\
\text { category }\end{array}$} \\
\hline Heterosexual & 55 & 36.4 & 80 & 24.3 & 135 & 28.1 & 39 & 11.7 & 174 & 21.4 \\
\hline Homosexual/Bisexual & 108 & 71.5 & 151 & 45.9 & 259 & 54.0 & 118 & 35.5 & 337 & 41.5 \\
\hline IDU & 129 & 85.4 & 201 & 61.1 & 330 & 68.8 & 113 & 34.0 & 443 & 54.6 \\
\hline Vertical transmission & 104 & 68.9 & 150 & 45.6 & 254 & 52.9 & 79 & 23.8 & 333 & 41.0 \\
\hline $\begin{array}{l}\text { Transfusion (blood/ } \\
\text { blood products) }\end{array}$ & 77 & 51.0 & 51 & 15.5 & 128 & 26.7 & 14 & 4.2 & 142 & 17.5 \\
\hline
\end{tabular}

(continues) 


\begin{tabular}{|c|c|c|c|c|c|c|c|c|c|c|}
\hline \multirow[t]{2}{*}{ Characteristics } & \multicolumn{2}{|c|}{1998} & \multicolumn{2}{|c|}{$\begin{array}{l}\text { Included } \\
2003\end{array}$} & \multicolumn{2}{|c|}{ Total } & \multicolumn{2}{|c|}{ Not included } & \multicolumn{2}{|c|}{$\begin{array}{l}\text { Total number of } \\
\text { Municipalities }\end{array}$} \\
\hline & $\mathrm{n}$ & $\%$ & $\mathrm{n}$ & $\%$ & $\mathrm{n}$ & $\%$ & $\mathrm{n}$ & $\%$ & $\mathrm{n}$ & $\%$ \\
\hline $\begin{array}{l}\text { Showed decrease in } \\
\text { mortality rate } \\
\text { Showed indicator } \\
\text { above the mean } \\
\text { for Brazilian } \\
\text { Municipalities }\end{array}$ & 85.0 & 56.3 & 156.0 & 47.6 & 241 & 50.3 & 103 & 31.0 & 344 & 42.4 \\
\hline $\begin{array}{l}\text { Late HIV diagnosis } \\
\text { (mean: 62.5\%) }\end{array}$ & 4 & 2.6 & 38 & 11.6 & 42 & 8.8 & 65 & 19.6 & 107 & 13.2 \\
\hline $\begin{array}{l}\text { Diagnosis at death } \\
\text { (mean: } 33.3 \% \text { ) }\end{array}$ & 5 & 3.3 & 18 & 5.5 & 23 & 4.8 & 28 & 8.4 & 51 & 6.3 \\
\hline $\begin{array}{l}\text { CD4+ T cell tests } \\
\text { per patient/year } \\
\text { (mean: } 1.69 \text { ) }\end{array}$ & 93 & 61.6 & 209 & 63.5 & 302 & 62.9 & 188 & 56.6 & 490 & 60.3 \\
\hline $\begin{array}{l}\text { Presented AIDS } \\
\text { services }\end{array}$ & & & & & & & & & & \\
\hline $\begin{array}{l}\text { Outpatient } \\
\text { VCT or supply } \\
\text { of HIV tests/ } \\
\text { inhabitants above } \\
\text { the mean ( } 17.1 \text { per } \\
1,000)\end{array}$ & $\begin{array}{l}118 \\
143\end{array}$ & $\begin{array}{l}78.1 \\
94.7\end{array}$ & $\begin{array}{l}163 \\
200\end{array}$ & $\begin{array}{l}49.5 \\
60.8\end{array}$ & $\begin{array}{l}281 \\
343\end{array}$ & $\begin{array}{l}58.5 \\
71.5\end{array}$ & $\begin{array}{l}39 \\
79\end{array}$ & $\begin{array}{l}11.7 \\
23.8\end{array}$ & $\begin{array}{l}320 \\
422\end{array}$ & $\begin{array}{l}39.4 \\
52.0\end{array}$ \\
\hline $\begin{array}{l}\text { STD/AIDS } \\
\text { consultations in } \\
\text { primary care above } \\
\text { the national mean } \\
\text { ( } 5.5 \text { per 100,000 } \\
\text { inhabitants) }\end{array}$ & 8 & 5.3 & 25 & 7.6 & 33 & 6.9 & 46 & 13.9 & 79 & 9.7 \\
\hline $\begin{array}{l}\text { More than } 75 \% \\
\text { of schools with } \\
\text { prevention } \\
\text { activities }\end{array}$ & 83 & 55.0 & 157 & 47.7 & 240 & 50.0 & 158 & 47.6 & 398 & 49.0 \\
\hline Health structure & & & & & & & & & & \\
\hline $\begin{array}{l}\% \text { primary } \\
\text { procedures (SUS) }\end{array}$ & 46.2 & - & 53.8 & - & 51.4 & - & 65 & - & 57.1 & - \\
\hline $\begin{array}{l}\text { Per capita } \\
\text { annual health } \\
\text { expenditures (R\$) }\end{array}$ & 219.4 & - & 179.2 & - & 191.8 & - & 172 & - & 183.8 & - \\
\hline
\end{tabular}

VCT: Voluntary Counseling and Testing Centers; HDI-M: Municipal Human Development Index; IDU: injecting drug user; SUS: Unified National Health System; $\mathrm{R} \$$ : Brazilian Reais.

consisting of 12 State capitals (Zres: 3.19), included the largest population (average of 518 thousand inhabitants) and the most AIDS cases, with $51.1 \%$ of the total in the Municipalities included in the Incentive.

b) Profile 2, with a comprehensive response and lower capacity for intervention: consisted of 60 Municipalities (14.1\%), the ones with the best performance in meeting $(86.7 \%)$ the set of minimum goals for the response to HIV, especially those related to healthcare for persons with HIV (98.3\%) and prevention of vertical transmission (93.3\%). They also showed the widest diversity of population groups, including the highest proportions of cities with activities related to sex workers (68.3\%), drug users (46.7\%), homosexuals (33.3\%), and transvestites (18.3\%). However, none of the Municipalities in this group made investments focused on a greater proportion of services supply in prevention and care. It was 
AIDS response profiles in the context of the Ministry of Health's Incentive Policy. Brazil, Qualified Municipalities, 2006 *.

\begin{tabular}{|c|c|c|c|c|}
\hline \multirow[t]{3}{*}{ Characteristics } & \multicolumn{4}{|c|}{ Profiles } \\
\hline & $1(n=91)$ & $2(n=60)$ & $3(n=147)$ & $4(n=129)$ \\
\hline & $\%$ & $\%$ & $\%$ & $\%$ \\
\hline Municipalities & 21.3 & 14.1 & 34.4 & 30.2 \\
\hline \multicolumn{5}{|l|}{ Scope (\%) } \\
\hline Meets essential guidelines ** & 82.4 & 86.7 & 27.9 & - \\
\hline HIV prevention in specific population groups & 96.7 & 96.7 & 73.5 & 96.1 \\
\hline Diagnosis of HIV infection & 100.0 & 100.0 & 50.3 & 2.3 \\
\hline Prevention of vertical transmission, HIV and syphilis & 92.3 & 93.3 & 81.6 & 79.1 \\
\hline Healthcare for persons with HIV & 95.6 & 98.3 & 95.9 & 94.6 \\
\hline Diagnosis and treatment of STI carriers & 84.6 & 78.3 & 71.4 & 61.2 \\
\hline \multicolumn{5}{|l|}{ Population groups (\%) } \\
\hline Persons with HIV, pregnant women, and STI carriers, concurrently with care & 50.5 & 51.7 & 42.2 & 46.5 \\
\hline Homosexuals, gays, and MSM & 27.5 & 33.3 & - & 34.1 \\
\hline Female and male sex workers & 63.7 & 68.3 & - & 72.9 \\
\hline Transvestites and transgenders & 17.6 & 18.3 & - & 12.4 \\
\hline Drug users, including IDU & 61.5 & 46.7 & - & 47.3 \\
\hline Vulnerable populations *** & 79.1 & 81.7 & 61.9 & 76.0 \\
\hline Jail inmates population (inmates/detainees) & 26.4 & 15.0 & 20.4 & 23.3 \\
\hline No group with higher prevalence included in prevention & 4.4 & 5.0 & 100.0 & 8.5 \\
\hline No group with higher prevalence included in response & - & - & 98.0 & - \\
\hline \multicolumn{5}{|l|}{ Sustainability (\%) } \\
\hline Investment of Municipality's own resources in care and prevention & 51.6 & 26.7 & 37.4 & 32.6 \\
\hline \multicolumn{5}{|l|}{ Impact of investment } \\
\hline $\begin{array}{l}\text { Highest \% of resources allocated in supply of services and care in the area } \\
\text { of prevention }\end{array}$ & 67.0 & 11.7 & 40.1 & 51.2 \\
\hline $\begin{array}{l}\text { Highest \% of resources allocated in supply of services and care in the area } \\
\text { of care }\end{array}$ & 94.5 & 38.3 & 61.2 & 60.5 \\
\hline $\begin{array}{l}\text { Highest \% of resources allocated in supply of services and care in the area of } \\
\text { prevention and care }\end{array}$ & 100.0 & - & 58.5 & 58.1 \\
\hline
\end{tabular}

IDU: injecting drug users; MSM: men who have sex with men; STI: sexually transmitted infections.

* Analysis excludes the 54 Municipalities that did not have Action and Target Plans in the year 2006;

** Simultaneously includes guidelines for care for persons with HIV, diagnosis of HIV infection, vertical HIV transmission, and prevention in the general population and specific groups;

*** Includes, among others, land settlement populations, indigenous peoples, and children and adolescents in schools and communities.

also the group with the lowest percentage of cities with their own local resources allocated in these areas. It had the third highest average population (189 thousand) and the lowest proportion (9.6\%) of AIDS cases in the cities included in the Incentive. These Municipalities were concentrated in the North (Zres: 3.15) and South (Zres: 2.73) of Brazil, especially in the States of Tocantins, Santa Catarina, and Roraima.

c) Profile 3, with a limited response, excluding priority population groups: consisting of the largest number of Municipalities, 147 (34.4\%), this was the profile with the lowest inclusion of specific population groups, given that none of these cities conducted activities for groups with the highest HIV prevalence rates, besides having the least concurrent coverage $(42.2 \%)$ in care for persons with HIV, STI carriers, pregnant women, and HIV-exposed children. It also had the second lowest coverage in the set of essential goals for the response (27.9\%). A comparatively small proportion conducted separate activities for HIV diagnosis (50.3\%), prevention of vertical transmission $(81.6 \%)$, and diagnosis and treatment of STI (71.4\%). Sustainability (37.4\%) and investments in actions to promote intervention 
Demographic and epidemiological characteristics of Municipal Health Departments according to the AIDS response profile. Brazil, 2009.

\begin{tabular}{|c|c|c|c|c|c|c|c|c|c|c|c|c|c|c|c|}
\hline \multirow[t]{3}{*}{ Characteristics } & \multicolumn{12}{|c|}{ HIV/AIDS epidemic response profile } & \multicolumn{2}{|c|}{ Total } & \multirow[t]{3}{*}{$\mathrm{p}$-value } \\
\hline & \multicolumn{3}{|c|}{1} & \multicolumn{3}{|c|}{2} & \multicolumn{3}{|c|}{3} & \multirow[b]{2}{*}{$\mathrm{n}$} & \multicolumn{2}{|c|}{4} & \multirow[b]{2}{*}{$\mathrm{n}$} & \multirow[b]{2}{*}{$\%$} & \\
\hline & $\mathrm{n}$ & $\%$ & Zres & $\mathrm{n}$ & $\%$ & Zres & $\mathrm{n}$ & $\%$ & Zres & & $\%$ & Zres & & & \\
\hline $\begin{array}{l}\text { Geographic } \\
\text { region }\end{array}$ & & & & & & & & & & & & & & & $<0.001$ \\
\hline Central & 2 & 2.2 & -1.82 & 3 & 5.0 & -0.45 & 17 & 11.6 & 3.22 & 5 & 3.9 & -1.37 & 27 & 6.3 & \\
\hline North & 1 & 1.1 & -1.32 & 6 & 10.0 & 3.15 & 4 & 2.7 & -0.47 & 3 & 2.3 & -0.73 & 14 & 3.3 & \\
\hline Northeast & 16 & 17.6 & 1.42 & 10 & 16.7 & 0.88 & 14 & 9.5 & -1.59 & 16 & 12.4 & -0.29 & 56 & 13.1 & \\
\hline South & 19 & 20.9 & -0.53 & 22 & 36.7 & 2.73 & 26 & 17.7 & -1.87 & 31 & 24.0 & 0.35 & 98 & 23.0 & \\
\hline Southeast & 53 & 58.2 & 0.84 & 19 & 31.7 & -3.80 & 86 & 58.5 & 1.25 & 74 & 57.4 & 0.83 & 232 & 54.3 & \\
\hline $\begin{array}{l}\text { Location of } \\
\text { municipality }\end{array}$ & & & & & & & & & & & & & & & 0.052 \\
\hline State Capital & 12 & 13.2 & 3.19 & 4 & 6.7 & 0.20 & 4 & 2.7 & -2.11 & 6 & 4.7 & -0.82 & 26 & 6.1 & \\
\hline $\begin{array}{l}\text { Greater } \\
\text { Metropolitan } \\
\text { Area }\end{array}$ & 24 & 26.4 & -0.02 & 16 & 26.7 & 0.04 & 36 & 24.5 & -0.67 & 37 & 28.7 & 0.68 & 113 & 26.5 & \\
\hline $\begin{array}{l}\text { Area } \\
\text { Interior }\end{array}$ & 55 & 60.4 & -1.61 & 40 & 66.7 & -0.14 & 107 & 72.8 & 1.71 & 86 & 66.7 & -0.23 & 288 & 67.4 & \\
\hline Population & & & & & & & & & & & & & & & $<0.001$ \\
\hline$\geq 200,000$ & 44 & 48.4 & 4.38 & 21 & 35.0 & 0.96 & 26 & 17.7 & -3.95 & 36 & 27.9 & -0.55 & 130 & 16.0 & \\
\hline $50,000-199,000$ & 43 & 47.3 & -1.79 & 32 & 53.3 & -0.36 & 87 & 59.2 & 1.11 & 75 & 58.1 & 0.72 & 386 & 47.5 & \\
\hline$\leq 49,000$ & 4 & 4.4 & -3.14 & 7 & 11.7 & -0.73 & 34 & 23.1 & 3.54 & 18 & 14.0 & -0.31 & 297 & 36.5 & \\
\hline $\begin{array}{l}\text { Mean } \\
\text { population } \\
\text { (thousands) }\end{array}$ & 518.0 & - & - & 189.7 & - & - & 155.5 & - & - & 198.0 & - & - & 250.4 & - & $<0.001$ \\
\hline $\begin{array}{l}\text { Mean HDI-M } \\
\text { Health structure }\end{array}$ & 0.794 & - & - & 0.788 & - & - & 0.782 & - & - & 0.792 & - & - & 0.788 & - & 0.239 \\
\hline $\begin{array}{l}\text { Per capita } \\
\text { annual health } \\
\text { expenditures } \\
(R \$)\end{array}$ & 202.2 & - & - & 184.9 & - & - & 195.3 & - & - & 199.5 & - & - & 196.6 & - & 0.77 \\
\hline $\begin{array}{l}\% \text { primary } \\
\text { procedures } \\
\text { (SUS) }\end{array}$ & 48.4 & - & - & 51.9 & - & - & 51.8 & - & - & 50.3 & - & - & 50.6 & - & 0.479 \\
\hline $\begin{array}{l}\text { Inclusion in } \\
\text { municipalization } \\
\text { strategies }\end{array}$ & & & & & & & & & & & & & & & \\
\hline 2003 & 43 & 47.3 & -3.91 & 31 & 51.7 & -2.27 & 114 & 77.6 & 4.04 & 88 & 68.2 & 1.02 & 329 & 40.5 & $<0.001$ \\
\hline 1994-2002 & 48 & 52.7 & 3.91 & 29 & 48.3 & 2.27 & 33 & 22.4 & -4.04 & 41 & 31.8 & -1.02 & 152 & 18.7 & \\
\hline $\begin{array}{l}\text { AIDS } \\
\text { Epidemiological } \\
\text { indicators }\end{array}$ & & & & & & & & & & & & & & & \\
\hline $\begin{array}{l}\text { Mean incidence } \\
\text { per 100,000 } \\
\text { inhabitants } \\
(2006)\end{array}$ & 27.9 & - & - & 26.9 & - & - & 24.3 & - & - & 26.2 & - & - & 26.0 & - & 0.309 \\
\hline $\begin{array}{l}\text { Mean number } \\
\text { of AIDS cases } \\
(2002-2006)\end{array}$ & 863 & - & - & 246 & - & - & 183 & - & - & 259 & - & - & 360 & - & $<0.001$ \\
\hline $\begin{array}{l}\text { Mean time } \\
\text { since onset of } \\
\text { epidemic (year) }\end{array}$ & 21.5 & - & - & 20.6 & - & - & 20.1 & - & - & 21.0 & - & - & 20.7 & - & $<0.001$ \\
\hline
\end{tabular}

HDI-M: Municipal Human Development Index; SUS: Unified National Health System. 
(58.5\%) showed medium indicators, comparable to those in Profile 1. This group had the lowest average population (155 thousand inhabitants) and especially included cities with 20-49 thousand inhabitants (Zres: 3.54), concentrated in the Central West (Zres: 3.22) and in the States of Mato Grosso, Minas Gerais, and Amazonas. It had the lowest mean number of AIDS cases (183), accounting for $17.5 \%$ of the epidemic in the $\mathrm{Mu}-$ nicipalities included in the Incentive.

d) Profile 4, with a limited response, mainly focusing on prevention: consisted of 129 Municipalities (30.2\%) with the lowest comprehensive response, no city that concurrently contemplated the set of essential guidelines. It also had the lowest proportions of cities that conducted separate activities involving care for persons with HIV (94.6\%), prevention of vertical transmission of HIV and syphilis (79.1\%), diagnosis and treatment of STI (61.2\%), and HIV diagnosis (2.3\%). However, in relation to specific population groups, all of the Municipalities in this group included some social segment with higher prevalence rates, with the highest proportion of cities working with homosexuals $(34.1 \%)$ and sex workers $(72.9 \%)$ and the second highest working with drug users (47.3\%) and jail inmates (23.3\%). Only about one-third (32.6\%) of these Municipalities allocated their own local resources concurrently in the areas of prevention and care and conducted investments in the supply of services and care for the population. These Municipalities had the second largest mean number of AIDS cases $(21.7 \%$ of the epidemic) and mean population (198 thousand inhabitants) and included six State capitals and a major concentration of Municipalities in the States of Espírito Santo and Piauí.

The profiles analyzed here showed similar characteristics $(p>0.05)$ in relation to the proportion of investments in prevention (mean: $32.8 \%$ ) and for the general population (mean: $48 \%$ ) and targeting of activities for persons with HIV (mean: 98.1\%), STI carriers (mean: 93.2\%), and pregnant women and HIV-exposed children (mean: 93.2\%).

The Municipalities with more comprehensive responses included a higher proportion of cities incorporated into the Incentive from 1994 to 1998 (the equivalent of 1.9 times more than those included in 2003). The latter group represented $73.2 \%$ of the Municipalities with more limited response profiles.

Comparing Municipalities that were included to those not included (Table 4), the chance were higher for Municipalities with a larger supply of HIV diagnostic tests (OR = 15.0; 95\%CI: 5.6-40.1) and AIDS outpatient services (OR $=18.4$; 95\%CI: 8.4-40.5) to be included in the municipalization strategies from 1994 to 1998 . The same trend was true for Municipalities included in 2003, but with lower odds: $\mathrm{OR}=2.4$ (95\%CI: $1.6-3.8)$ and $\mathrm{OR}=$ 5.2 (95\%CI: 3.2-8.4), respectively. This characteristic becomes more evident to the extent that the Municipalities included in the Incentive had nearly all of the Anonymous Testing and Counseling Centers $(90.3 \%)$ and AIDS outpatient services $(87.8 \%)$ and $81.6 \%$ of the cities with HIV diagnostic services above the national average, performing 2.1 times more tests per 100 thousand inhabitants/year than the mean for the cities studied (Table 1).

However, the fact that Municipalities included in the Incentive had a greater supply of AIDS services did not mean higher chance of performing timely diagnosis or making CD4+/CD8+ Tcell testing available at rates above the national average. Thus, the chance of showing a reduction in the mortality rate were not associated with any of the groups analyzed, except when this trend was analyzed independently of the presence of AIDS services. In this situation, the reduction in mortality was associated with the Municipalities included in 2003.

There was also no association between wider coverage of preventive activities and inclusion in the Incentive. The proportions were similar for cities included and not included in the Incentive that conducted preventive activities in more than $75 \%$ of the schools and that conducted more STI/ AIDS consultations in primary care clinics.

On the other hand, the downward trends in the number of cases among IDU $(\mathrm{OR}=6.6$; 95\%CI: 2.9-14.9) and due to sexual transmission, whether heterosexual (OR $=3.1$; 95\%CI: 1.4-7.3) or homosexual/bisexual (OR = 3.0; 95\%CI: 1.4 6.2 ), were more closely associated with the Municipalities included from 1994 to 1998 . For the Municipalities included in 2003, the only related downward trend was in IDUs, but with lower odds (OR $=2.4$; 95\%CI: 1.5-3.7) (Figure 1). The Municipalities with a reduction in cases due to blood transfusions and vertical transmission did not show an association with any of the groups analyzed, independently of the year in which they were included. There were important proportions of Municipalities with upward trends in cases due to vertical transmission $(31.2 \%)$ and transfusions (17.4\%).

\section{Discussion}

The strategies the municipalization contributed to the induction of profiles in response to the AIDS epidemic that were different in their scope, degrees of inclusion of population groups, sus- 
Crude and adjusted odds ratios according to multinomial logistic regression of epidemiological and health services indicators in the Municipalities included in the Ministry of Health's municipalization strategies for AIDS in 1998 and 2003, as compared to Municipalities not included.

\begin{tabular}{|c|c|c|c|c|c|c|c|c|}
\hline $\begin{array}{l}\text { Municipalities included in } \\
\text { municipalization in } 1998(n=151)\end{array}$ & Categories & $\begin{array}{l}\% \text { Included } \\
\text { in } 1998\end{array}$ & $\begin{array}{c}\% \text { Not } \\
\text { included }\end{array}$ & $\begin{array}{c}\text { Crude } \\
\text { OR }\end{array}$ & p-value & $\begin{array}{l}\text { Adjusted } \\
\text { OR* }\end{array}$ & $95 \% \mathrm{Cl}$ & $\mathrm{p}$-value \\
\hline Presence of VCT or supply of HIV & No & 5.3 & 76.2 & 1 & $<0.001$ & 1 & & \\
\hline $\begin{array}{l}\text { tests above the mean ( } 17.1 \text { per } 1,000 \\
\text { inhabitants) }\end{array}$ & Yes & 94.7 & 23.8 & 57.2 & & 15.0 & $5.6-40.1$ & $<0.001$ \\
\hline \multirow[t]{2}{*}{ Presence of AIDS outpatient clinic } & No & 21.9 & 88.3 & 1 & $<0.001$ & 1 & & \\
\hline & Yes & 78.1 & 11.7 & 26.9 & & 18.4 & $8.4-40.5$ & $<0.001$ \\
\hline Reduction in transmission among & No & 63.6 & 88.3 & 1 & & 1 & & \\
\hline heterosexuals & Yes & 36.4 & 11.7 & 4.3 & $<0.001$ & 3.1 & $1.4-7.3$ & 0.008 \\
\hline Reduction in transmission among & No & 28.5 & 64.5 & 1 & & 1 & & \\
\hline homosexuals & Yes & 71.5 & 35.5 & 4.5 & $<0.001$ & 3.0 & $1.4-6.2$ & 0.003 \\
\hline \multirow[t]{2}{*}{ Reduction in transmission in IDU } & No & 14.6 & 66 & 1 & & 1 & & \\
\hline & Yes & 85.4 & 34 & 11.4 & $<0.001$ & 6.6 & $2.9-14.9$ & $<0.001$ \\
\hline $\begin{array}{l}\text { Municipalities included in } \\
\text { municipalization in } 2003(n=329) \text { ** }\end{array}$ & Categories & $\begin{array}{l}\% \text { Included } \\
\text { in } 2003\end{array}$ & $\begin{array}{c}\% \text { Not } \\
\text { included }\end{array}$ & $\begin{array}{c}\text { Crude } \\
\text { OR }\end{array}$ & $p$-value & $\begin{array}{l}\text { Adjusted } \\
\text { OR * }\end{array}$ & $95 \% \mathrm{Cl}$ & p-value \\
\hline Presence of VCT or supply of HIV & No & 39.2 & 76.2 & 1 & $<0.001$ & 1 & & \\
\hline $\begin{array}{l}\text { tests above the mean ( } 17.1 \text { per } 1,000 \\
\text { inhabitants) }\end{array}$ & Yes & 60.8 & 23.8 & 5 & & 2.4 & $1.6-3.8$ & $<0.001$ \\
\hline \multirow[t]{2}{*}{ Presence of AIDS outpatient clinic } & No & 50.5 & 88.3 & 1 & $<0.001$ & 1 & & \\
\hline & Yes & 49.5 & 11.7 & 7.4 & & 5.2 & $3.2-8.4$ & $<0.001$ \\
\hline Reduction in transmission among & No & 75.7 & 88.3 & 1 & $<0.001$ & 1 & & \\
\hline heterosexuals & Yes & 24.3 & 11.7 & 2.4 & & 1.6 & $0.9-2.8$ & 0.085 \\
\hline Reduction in transmission among & No & 54.1 & 64.5 & 1 & 0.004 & 1 & & \\
\hline homosexuals & Yes & 45.9 & 35.5 & 1.5 & & 1.3 & $0.8-1.9$ & 0.287 \\
\hline \multirow[t]{2}{*}{ Reduction in transmission in IDU } & No & 38.9 & 66 & 1 & & 1 & & \\
\hline & Yes & 61.1 & 34 & 3 & $<0.001$ & 2.4 & $1.5-3.7$ & $<0.001$ \\
\hline
\end{tabular}

* Model adjusted according to the proportion of primary procedures among all procedures performed under the Unified National Health System, municipal population in 2006, and time since onset of the epidemic in the Municipality;

** Significance in the final model $<0.001$.

VCT: Voluntary Counseling and Testing Centers; IDU: injecting drug users; SUS: Unified National Health System.

tainability, and capacity to intervene in the epidemic. The most comprehensive profiles were associated with the Municipalities that have been included longer in the processes to expand the response, and they in turn showed the best results in the supply of services and the reduction of cases among heterosexuals, homosexuals/bisexuals, and IDU. Meanwhile, the municipalization strategies were not associated with wider coverage of preventive activities or reduction in mortality or AIDS cases due to vertical transmission or transfusions.

These findings should be interpreted with the study's limitations in mind. Due to the study design and the specificities of its object, it is not possible to establish exclusive causal relations between the municipalization process, the greater supply of services, and changes in epidemiological trends. First, the development of actions and the epidemic's behavior result from multiple factors and the work of numerous government institutions and civil society organizations in more than 25 years of response to AIDS 1,2,9. Municipalization is one of these factors, making an important contribution to the expansion and consolidation of the response by encouraging States and Municipalities to organize and finance their programs.

Second, the analysis of the effects of municipalization on the epidemiological trends was based on AIDS cases, while the long latency of HIV infection tends to make this measurement 
Figure 1

Time trend in the mean number of AIDS cases reported in Municipalities included and not included in the Ministry of Health's municipalization strategies, according to transmission category. Brazil, 1998-2006.

1a) Homosexuals and bisexuals

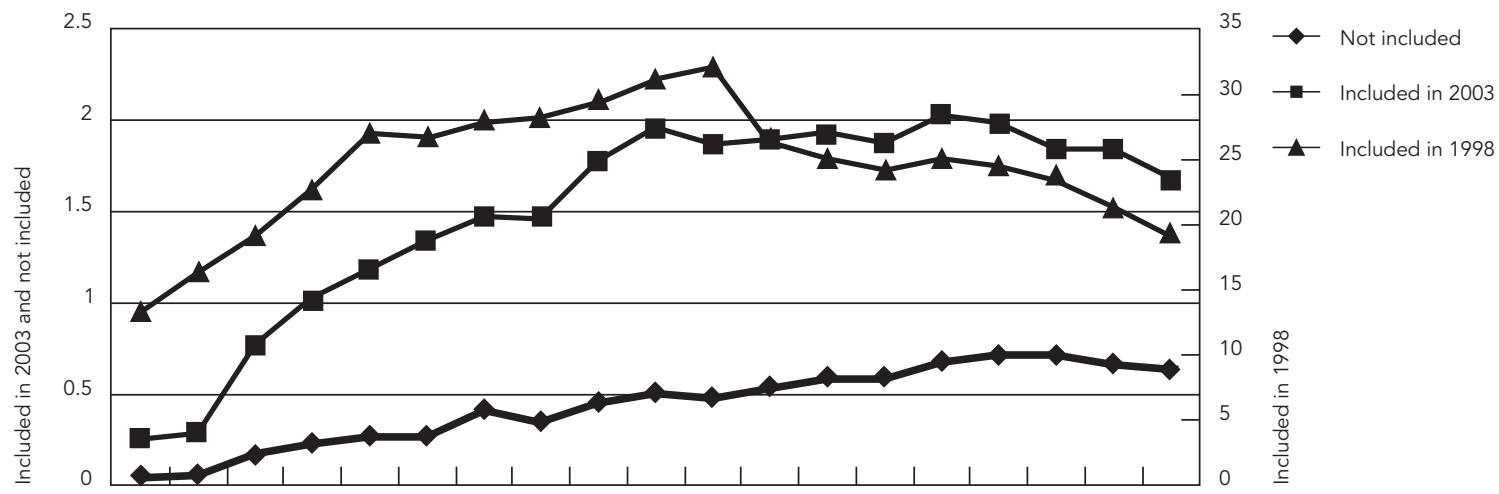

1988198919901991199219931994199519961997199819992000200120022003200420052006

1b) Heterosexual

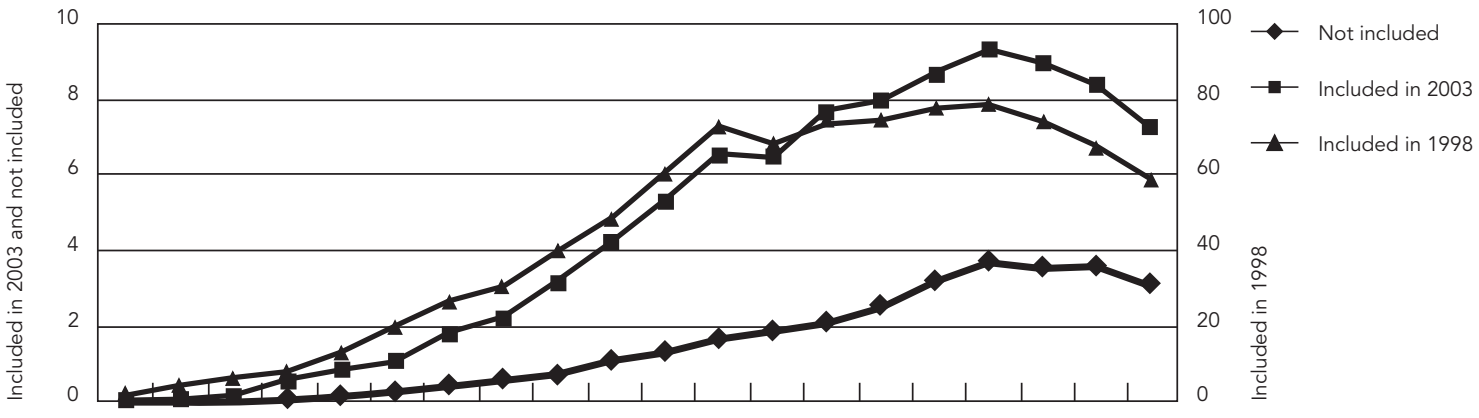

19871988198919901991199219931994199519961997199819992000200120022003200420052006

1c) Injecting drug user
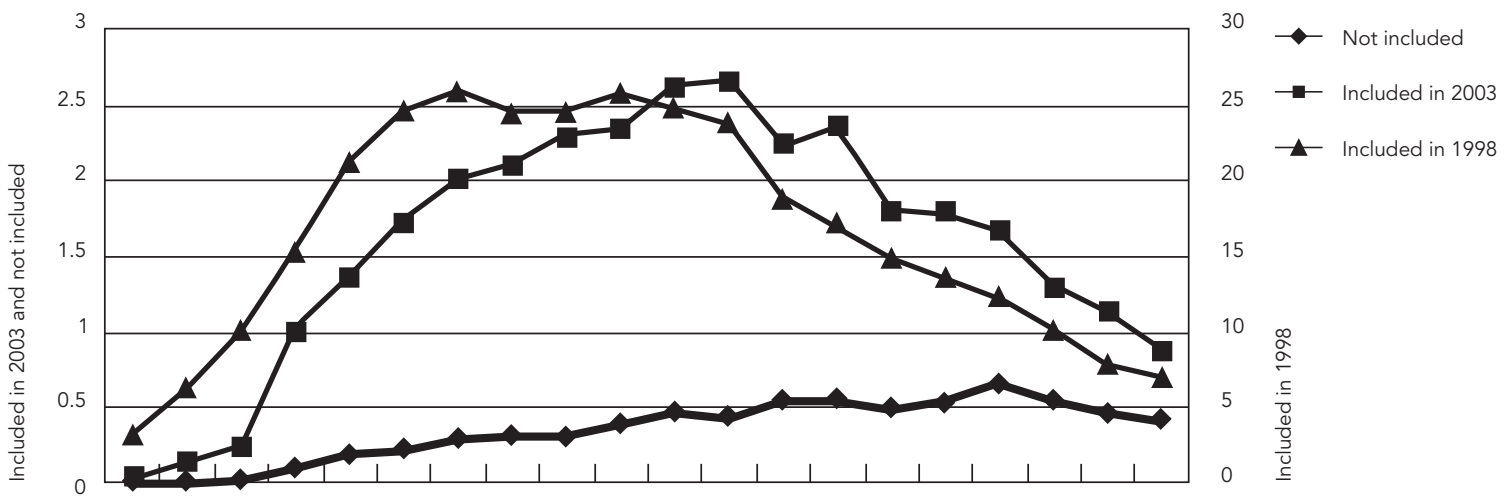

19871988198919901991199219931994199519961997199819992000200120022003200420052006 
imprecise. Thus, at one extreme, one might suppose that the reduction in the number of AIDS cases observed since 1997 was entirely associated with the infections that failed to occur prior to that year, rather than to the interventions promoted by municipalization.

However, the current study's findings allow us to point in a different direction, namely that there is a clear hierarchy in the chances of the municipalities show a downward trend in cases, according to the time of inclusion in the mucipalization strategies. Thus, Municipalities that were not included showed upward trends and those included from 1994 to 1998 tended to be associated with a reduction in cases. This fact allows us to suppose that if the reduction in cases began prior to the municipalization strategies, it was expanded and intensified after this event, and its effects will be felt more strongly over time.

This finding is also reinforced by other aspects. The chance are significant that an important share of the cases were averted during the period analyzed. Various studies indicate that the mean time between infection and development of AIDS varies from 7 to 11 years, with slightly more than half of the cases of HIV infection presenting the disease before this time ${ }^{18}$. Importantly, some of these studies adopt a definition of AIDS (CD4+/CD8+ T-cell count $<200$ cells $/ \mathrm{mm}^{3}$ ) with lower sensitivity than the Brazilian definition (CD4+/CD8+ T-cell count $<350$ cells $/ \mathrm{mm}^{3}$ ), thus leading to later identification of cases 19 .

Furthermore, none of the Municipalities that showed a reduction in cases in heterosexuals had displayed this trend before 1998. Among those with a reduction in homosexuals, this proportion was $16.5 \%$, and more than one-third had been included in municipalization since 1994.

Finally, the analysis was adjusted for factors that could intervene in the understanding of the association between a downward trend in cases and municipalization, like the epidemic's maturity, the response influenced by greater complexity in the health system, and the existence of different contexts of vulnerability due to the municipality's size.

An important part of the positive results in Brazil's AIDS policy may be related to the $\mathrm{Mu}-$ nicipalities with more comprehensive response profiles, which include an important share of the cities incorporated into the municipalization strategies from 1994 to 1998 and the largest proportion of AIDS cases that occurred during the period analyzed. These profiles are close to those of successful experiences in various parts of the world 20 and the guidelines for the Brazilian response 1,2,9, while differing from the other Municipalities because they present characteris- tics with a more balanced combination of scope, inclusion of specific population groups, sustainability, and greater capacity to intervene in the epidemic, due to actions targeting the population with the highest prevalence and major investments in the provision of services.

The structuring of the response to AIDS in Brazil may also help understand the lack of association between municipalization and the reduction in cases due to vertical transmission or transfusions. The reduction in these transmission categories was significant throughout Brazil due to structural changes 1,9 that encompassed Municipalities both included and not included in municipalization. In the case of transmission by blood and blood products, the implementation of the national policy in the 1980s 9,21 banned commercialization of the blood, stimulated the implementation of transfusion centers, and introduced mandatory serological screening of donations. As for vertical transmission, since 2000, mandatory diagnosis and treatment of HIV infection was incorporated nationwide into the prenatal, childbirth, and postpartum services system, thus facilitating the decrease in motherto-child transmission 22,23.

Importantly, these problems have still not been overcome. The residual risk of transfusionrelated HIV infection remains greater in Brazil than in high-income countries 24 , due largely to persistent reliance on blood banks for HIV testing (blood banks are the main source of HIV testing among Brazilian men) 25. As for vertical transmission, the Brazilian results are inferior to those of some other middle-income countries like Argentina, Botswana, and Thailand 26. Brazil's coverage is estimated at around $40 \%$, depending on the region of the country 27,28 , thus meaning a missed opportunity to avert cases (on the order of 56\%) 30 . Greater prioritization of these issues by the Incentive Policy is needed to help reverse this situation.

The study showed strong capacity by municipalization policies to induce the implementation of services and to strengthen the local health system. However, this structure was not associated with greater reduction of mortality rates. One hypothesis is that the services in Municipalities included in the Incentive are acting as references for treatment of persons with HIV residing in $\mathrm{Mu}-$ nicipalities not included, thereby contributing to the homogenization of the reduction in mortality rates. The "regionalization" of care is characteristic of the Brazilian health system in the treatment of more complex diseases, as discussed previously 30 .

However, when the analysis was adjusted for the existence of services, the Municipalities in- 
cluded in 2003 showed higher chance of reducing mortality. This could reflect the incorporation of new technologies in the initial phases of the Incentive, with a positive impact on quality of care for persons with HIV. On this assumption, the impact of the incorporation of new technologies on mortality probably occurred earlier in the Municipalities included from 1994 to 1998.

A similar capacity to induce the expansion of healthcare serves was not observed in the area of prevention. This situation was unexpected, given that the guidelines for the Brazilian response and the Incentive Policy ascribe equal importance to prevention and care. The lower degree of development of prevention activities has been discussed previously 10 and may relate partially to the characteristics of the Brazilian health system, which shows incipient coverage in primary care in large cities 31 , where the epidemic is concentrated, and the lower priority of health promotion activities as compared to individual patient care.

In prevention, the analysis of the response profile for Municipalities included under the Incentive revealed the exclusion of population groups with the highest HIV prevalence (and this was true, to varying degrees, in Municipalities with more limited as well as more comprehensive responses). This issue clearly revealed a mismatch between the characteristics of the response by the Municipalities, emphasizing measures for the general population, and the epidemic's profile, heavily concentrated in specific groups like IDU and homosexuals/bisexuals, who show a significantly higher risk of infection than the general population ${ }^{31}$.

These population groups have repeatedly been excluded from the response to the epidemic in various contexts in Latin America, Asia, and Africa 20, due to numerous situations of prejudice that create barriers against access to health promotion activities 7,20 . Once these obstacles are overcome, the Brazilian results should be more significant.

Fifty-four Municipalities were not included in the analysis of the response profile, since they were incorporated into the Incentive after 2006. These Municipalities typically had smaller epidemics and small to medium-sized populations, similar to the cities with more limited response profiles. One can assume that the inclusion of these Municipalities in the response profile model would not alter the findings, since no significant changes occurred between 2007 and 2008 in the Incentive Policy's guidelines.

In short, this study's findings showed that induction of the response through the transfer of Federal funds and the establishment of technical guidelines strengthens decentralized health structures, which to a greater or lesser degree foster more effective control of the epidemic: more comprehensive responses are associated with the best results. However, limitations to the response, especially in the area of prevention, minimize the actions' impact and should be the object of further intervention.

\footnotetext{
Resumo

Avaliar as estratégias do Ministério da Saúde para ampliar a resposta municipal a AIDS. Cidades "incluídas" e "não incluídas" nas estratégias federais de municipalização foram comparadas segundo perfil da resposta e da epidemia. Regressão logística multinomial foi usada, entre outros procedimentos estatísticos. Municípios incluídos entre 1994/98 apresentaram maior chance de ofertar o diagnóstico do HIV $[O R=15,0$; IC95\%: 5,6-40,1], possuir serviços de AIDS [OR = 18,4; IC95\%: 8,4-40,5] e reduzir casos por transmissão heterossexual [OR = 3,1; IC95\%: 1,4-7,3], homo/bissexual [OR = 3,0; IC95\%: 1,4-6,2] e uso de drogas injetáveis
}

[OR = 6,6; IC95\%: 2,9-14,9] do que os "incluídos em 2003" e os "não incluídos". Não houve associações entre municípios incluídos, a maior cobertura de prevenção e a redução de casos por transmissão vertical, transfusão de sangue e taxas de mortalidade. Municípios com resposta mais estruturada associam-se a melhores resultados. Os achados sugerem que a política de municipalização contribuiu para aprimorar a resposta.

Síndrome de Imunodeficiência Adquirida; Avaliação de Programas e Projetos de Saúde; Prevenção de Doenças; Descentralização 


\section{Contributors}

A. Grangeiro and M. M. L. Escuder participated in the original concept, data analysis, and writing of the article. E. A. Castilho participated in the data analysis and writing of the article.

\section{Acknowledgments}

The authors wish to thank the staff at the Planning Units of the National Department of STD, AIDS, and Viral Hepatitis under the Brazilian Ministry of Health and the São Paulo State AIDS Program, especially Sérgio D'Avila, Maria Alice Tironi, Sandra Regina Miguel, Sara Sorrentino, and Vilma Cervantes, for their contributions to the discussions on the Incentive Policy and for providing information and data, as well as Paulo Roberto Teixeira for his critical analysis.

\section{References}

1. Berkman A, Garcia J, Muñoz-Laboy M, Paiva V, Parker R. A critical analysis of the Brazilian response to HIV/AIDS: lessons learned for controlling and mitigating the epidemic in developing countries. Am J Public Health 2005; 95:1162-72.

2. Grangeiro A, Laurindo-Silva L, Teixeira PR. Resposta à AIDS no Brasil: contribuições dos movimentos sociais e da reforma sanitária. Rev Panam Salud Pública 2009; 26:87-94.

3. Teixeira PR, Vitória MA, Barcarolo J. Antiretroviral treatment in a resource-poor setting: the Brazilian experience. AIDS 2004; 18 Suppl 3:S5-7.

4. Fonseca MGP, Bastos FI. Twenty-five years of the AIDS epidemic in Brazil: principal epidemiological findings, 1980-2005. Cad Saúde Pública 2007; 23 Suppl 3:S333-44.

5. Berquó E, Barbosa RM, Lima LP; Grupo de Estudos em População, Sexualidade e AIDS. Uso do preservativo: tendências entre 1998 e 2005 na população brasileira. Rev Saúde Pública 2008; 42 Suppl 1: 34-44.

6. Caiaffa WT, Bastos FI, Freitas LL, Mingoti SA, Proietti FA, Carneiro-Proetti AB, et al. The contribution of two Brazilian multi-center studies to the assessment of HIV and HCV infection and prevention strategies among injecting drug users: the AjUDEBrasil I and II Projects. Cad Saúde Pública 2006; 22:771-82.
7. Garcia S, Koyama MAH; Grupo de Estudos em População, Sexualidade e AIDS. Estigma, discriminação e HIV/AIDS no contexto brasileiro, 1998 e 2005. Rev Saúde Pública 2008; 42 Suppl 1:72-83.

8. Hacker MA, Kaida A, Hogg RS, Bastos FI. The first ten years: achievements and challenges of the Brazilian program of universal access to HIV/AIDS comprehensive management and care, 1996 -2006. Cad Saúde Pública 2007; 23 Suppl 3:S345-59.

9. Teixeira PR. Políticas públicas em AIDS. In: Parker R, editor. Políticas, instituições e AIDS: enfrentando a epidemia no Brasil. Rio de Janeiro: Associação Brasileira Interdisciplinar de AIDS; 1997. p. 43-68.

10. Paiva $\mathrm{V}$, Pupo LR, Barboza R. $\mathrm{O}$ direito à prevenção e os desafios da redução de vulnerabilidade ao HIV no Brasil. Rev Saúde Pública 2006; 40 Suppl: 109-19.

11. World Bank. Project performance assessment report: Brazil first and second AIDS and STD control projects (Loan 3659-BR and 4392-BR). Operations Evaluation Department, 2004. http://www.world bank.org/ (accessed on 15/Jul/2008).

12. Barboza R. Gestão do Programa Estadual DST/ AIDS de São Paulo: uma análise do processo de descentralização das ações no período de 1994 a 2003 [Masters Thesis]. São Paulo: Coordenadoria de Controle de Doenças, Secretaria de Estado da Saúde de São Paulo; 2006. 
13. Pires DRF. Alguns apontamentos sobre o processo de descentralização do programa de AIDS [Masters Thesis]. Rio de Janeiro: Instituto de Medicina Social, Universidade do Estado do Rio de Janeiro; 2006.

14. Taglieta MFB. Avaliação da implantação do incentivo no âmbito do Programa Nacional de HIV/AIDS e outras DST em dois municípios do estado de São Paulo [Masters Thesis]. Rio de Janeiro: Escola Nacional de Saúde Pública, Fundação Oswaldo Cruz; 2006.

15. Ministério da Saúde. Programa Nacional de DST e Aids. http://www.pam.aids.gov.br/pam/ (accessed on $17 /$ Mar/2008).

16. Pereira JCR. Análise de dados qualitativos: estratégias metodológicas para as ciências da saúde, humanas e sociais. 3a Ed. São Paulo: Edusp; 2001.

17. Fox J. Applied regression analysis and generalized linear models. 2nd Ed. London: Sage Publications; 2008.

18. Time from HIV-1 seroconversion to AIDS and death before widespread use of highly-active antiretroviral therapy: a collaborative re-analysis. Collaborative Group on AIDS Incubation and HIV Survival including the CASCADE EU Concerted Action. Concerted Action on SeroConversion to AIDS and Death in Europe. Lancet 2000; 355:1131-37.

19. Campos DP, Ribeiro SR, Grinsztejn B, Veloso VG, Valente JG, Bastos FI, et al. Survival of AIDS patients using two case definitions, Rio de Janeiro, Brazil, 1986-2003. AIDS 2005; 19 Suppl 4:S22-6.

20. Piot P, Bartos M, Larson H, Zewdie D, Mane P. Coming to terms with complexity: a call to action for HIV prevention. Lancet 2008; 372:845-59.

21. Junqueira PC, Rosemblit J, Hamerschlak N. História da hemoterapia no Brasil. Rev Bras Hematol Hemoter 2005; 27:201-7.

22. Serruya SJ, Cecatti JG, Lago TG. O Programa de Humanização do Pré-natal e Nascimento do Ministério da Saúde no Brasil: resultados iniciais. Cad Saúde Pública 2004; 20:1281-9.
23. Succi RCM; Grupo de Estudos da Sociedade Brasileira de Pediatria para Avaliar a Transmissão Materno-Infantil do HIV. Mother-to-child transmission of HIV in Brazil during the years 2000 and 2001: results of a multi-centric study. Cad Saúde Pública 2007; 23 Suppl 3:S379-89.

24. Maresch C, Schluter PJ, Wilson AD, Sleig A. Residual infectious disease risk in screened blood transfusion from a high-prevalence population: Santa Catarina, Brazil. Transfusion 2008; 48:273-81.

25. França Junior I, Calazans G, Zucchi EM; Grupo de Estudos em População, Sexualidade e AIDS. Mudanças no âmbito da testagem anti-HIV no Brasil entre 1998 e 2005. Rev Saúde Pública 2008; 42 Suppl 1:84-97.

26. United Nations Joint Programme on HIV/AIDS. Report on the global AIDS epidemic 2008. Geneva: United Nations Joint Programme on HIV/AIDS; 2008.

27. Szwarcwald CL, Barbosa Júnior A, Souza Júnior PRB, Lemos KRV, Frias PG, Luhm KR, et al. HIV testing during pregnancy: use of secondary data to estimate 2006 test coverage and prevalence in Brazil. Braz J Infect Dis 2008; 12:167-72.

28. Veloso VG, Portela MC, Vasconcellos MTL, Matzenbacher LA, Vasconcelos ALR, Grinsztejn B, et al. HIV testing among pregnant women in Brazil: rates and predictors. Rev Saúde Pública 2008; 42:859-67.

29. Rodrigues CS, Guimarães MDC, César CC. Missed opportunities for congenital syphilis and HIV perinatal transmission prevention. Rev Saúde Pública 2008; 42:851-8.

30. Reis CT, Czeresnia D, Barcellos C, Tassinari WS. A interiorização da epidemia de HIV/AIDS e o fluxo intermunicipal de internação hospitalar na Zona da Mata, Minas Gerais, Brasil: uma análise espacial. Cad Saúde Pública 2008; 24:1219-28.

31. Barbosa Júnior A, Szwarcwald CL, Pascon ARP, Souza Junior PB. Tendências da AIDS epidemic entre subgrupos sob maior risco no Brasil, 19802004. Cad Saúde Pública 2009; 25:727-37.

Submitted on 14/Dec/2009

Final version resubmitted on 06/Apr/2010

Approved on 19/Apr/2010 